\title{
Admiral Lord Nelson's death: known and unknown - A historical review of the anatomy
}

\author{
D Wang*,1, WS El-Masry ${ }^{2}, \mathrm{M} \mathrm{Crumplin}^{3}$, S Eisenstein ${ }^{2}$, RJ Pusey ${ }^{4}$ and T Meagher ${ }^{1}$ \\ ${ }^{1}$ National Spinal Injuries Centre, Stoke Mandeville Hospital, Aylesbury, Buckinghamshire, UK; ${ }^{2}$ The Midland Centre \\ for Spinal Injuries, The Robert Jones \& Agnes Hunt Orthopaedic and District Hospital NHS Trust, Oswestry, \\ Shropshire, UK; ${ }^{3}$ Hunterian Museum and Royal College of Surgeons, Treasurer of the Waterloo Committee, \\ Marford, Wrexham UK, ${ }^{4}$ Department of Anatomy, University College London, London, UK
}

\begin{abstract}
Study design: Reviewing documents about Lord Admiral Nelson's wound inflicted at the Battle of Trafalgar and studying the collected data in connection with ballistics and human anatomy.

Objectives: Attempting to find out the actual cause of death of Lord Nelson as soon as $4 \mathrm{~h}$ postinjury by a musket ball.

Setting: United Kingdom.

Methods: (1) Review of the original report of Mr W Beatty, Lord Nelson's surgeon, on his examination of His Lordship's wound. (2) Investigating the course of the musket ball in connection with an atlas of human anatomy. (3) Investigating the course of the musket ball on a cadaver by RP (one of the authors). (4) Reviewing modern medical literature.

Results: The report of Mr Beatty suggested that division of a large branch of the pulmonary artery was the cause of Lord Nelson's early death. Assuming the left pulmonary artery was injured, anatomical studies based on atlases and dissection on a cadaver failed to support a simple straight-line course of the musket ball that could have divided the artery and damage the spinal cord on its path forward.

Conclusion: The question remains open as to how the musket ball following a relatively straight-line trajectory by entering the body at the acromion, could have divided the left pulmonary artery and damaged the spinal cord later in its course. The mechanism needs further investigation.
\end{abstract}

Spinal Cord (2005) 43, 573-576. doi:10.1038/sj.sc.3101850; published online 13 September 2005

Keywords: the battle of Trafalgar; Admiral Lord Nelson; early death after injury; division of pulmonary artery

\section{Editor's note}

Horatio Nelson was born on 29 September 1758. His introduction to the Navy came from his uncle, Captain Maurice Suckling, who was an officer of some reputation. Nelson joined the Navy in 1770, and passed his examination as Lieutenant in April 1777. He was appointed Post Captain in 1779, and first saw active service in 1780 .

His heroic naval career was also marked by passionate attachments to women, dislike and contempt for the French, although this did not prevent him from forming yet another attachment in France, and political transactions and intrigues.

*Correspondence: D Wang, 11 Selkirk Avenue, Aylesbury, Buckinghamshire HP19 9QD, UK
He continued in active service from 1793 to 1800 , and this period was marked by the loss of his right eye in 1794, the loss of his arm in 1797 and the victory of the Nile in 1798. By this time he was a national hero and foremost among warriors of a war-like time. He was appointed to the Mediterranean command in 1803, and from this date until his death in October 1805 he was at the centre of the vast military and naval drama, which found its closing scene in Trafalgar. On 21 October 1805, he was walking up and down the quarter deck of his flag ship by the side of his Flag-Captain TM Hardy. As they turned, a musket shot struck him and, it is said, he uttered the words 'They have done for me at last!'.

Nelson had no children by his wife. His daughter, Horatia, by Lady Hamilton, died in 1881. In the 
inimitable English way, his brother William, in recognition of Nelsons' great services to his country, created Earl Nelson of Trafalgar, with an annuity of $£ 5,000.00$ being attached to the title.

\section{Introduction}

A visit by one of the authors (DW) to Burnham Thorpe, the birthplace of Admiral Lord Nelson (Figure 1) stimulated his interest in Nelson's life and death, particularly the Battle of Trafalgar.

He went to Portsmouth to see Lord Nelson's flagship, HMS Victory and the Royal Naval Museum, where records of the battle and Lord Nelson's death were kept. As a surgeon, he was particularly interested in the injury inflicted upon Nelson by a ball from a musket. The shot was fired at around 1315 hours on 21 October 1805 and Lord Nelson died $3 \mathrm{~h}$ and 15 min later at 1630 hours. In the detailed record on HMS Victory, the main injury was described as affecting the backbone (the spine). Other descriptions recorded loss of movement and sensation below the chest, implying spinal cord injury. However, some of these injuries, including injury of the left lung on the path of the musket ball, could not explain the death of His Lordship so soon after the injury despite bleeding a good deal. This prompted a further look into the cause of the early death, which is the purpose of this study.

\section{Materials and methods}

(1) The searching of materials recording details of Lord Nelson's wound and death started in late 2003. No

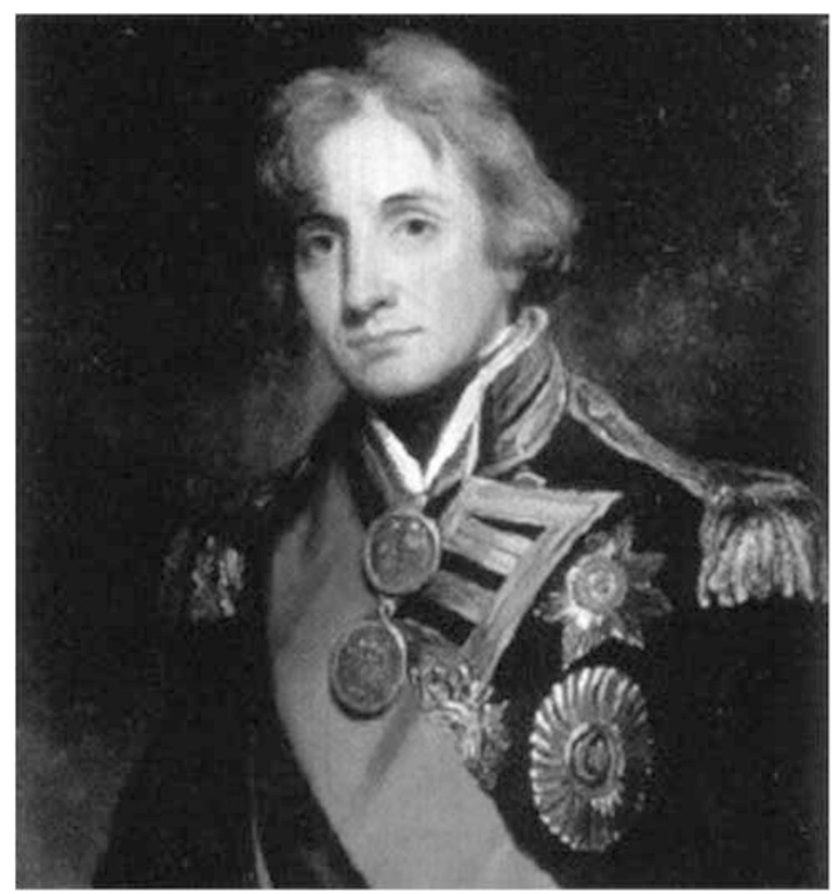

Figure 1 Painting of Lord Admiral Nelson. (Courtesy of the website Death/Burial, www.aboutnelson.co.uk/death.htm) detailed description was readily available to explain Lord Nelson's early death in any of his biographies and contemporary books on the Battle of Trafalgar. The website materials were studied because they were periodically updated with the latest information as the 200th anniversary of the Battle of Trafalgar was approaching. The website Death/Burial www.aboutnelson.co.uk/death.htm had the most detailed material, recording Nelson's condition from injury to death. ${ }^{1}$ Dr Colin $\mathrm{S}$ White was contacted. He is one of Britain's leading experts on Nelson and the Director of Trafalgar 200 at the National Maritime Museum. His kind reply included a photocopy of the relevant parts of the medical and autopsy report by Lord Nelson's surgeon, Mr W Beatty. It was from a historical book entitled The Battle of Trafalgar. Since this communication, the above-mentioned website has been updated with this new information. ${ }^{2}$

(2) Investigating the course of the musket ball described in Beatty's report in connection with atlases of human anatomy.

(3) Investigating the course of the musket ball described in Beatty's report on a cadaver by one of the authors (RP).

(4) Searching modern medical literature from 1963 to compare with Beatty's report.

\section{Results and discussion}

The battle of Trafalgar, between the British Royal Navy and the French-Spanish fleet broke out on 21 October 1805. Lord Nelson's tactic was unorthodox. He finally engaged the enemies at such a close range that it rendered telescopes and cannons less relevant. The principal weapons at such close range were grenades and musket balls (Figure 2). Most of the balls were made of lead. They are large-size balls of $0.57-0.69 \mathrm{in}$, in diameter and around $20 \mathrm{gm}$ in weight and of low velocity.

When the action started, Nelson was on the quarterdeck. He was later shot by a ball and collapsed. His symptoms and signs are described below. They give a clear picture of the injuries. Those within the quotation marks are his own words. Most of the injuries were identified by Lord Nelson himself.

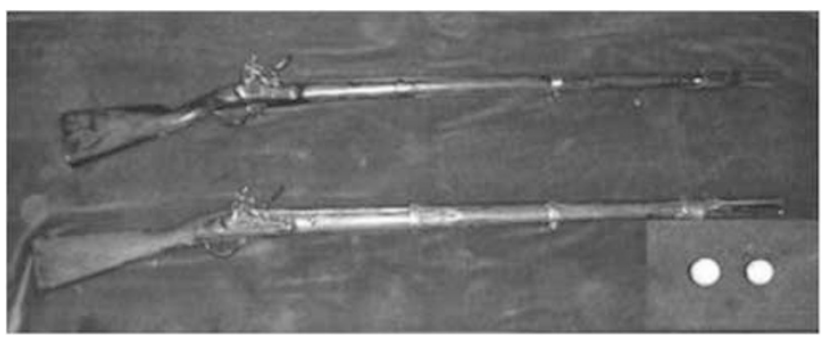

Figure 2 The French muskets and musket balls 
1. With back pain, he commented, 'My backbone is shot through!' This pointed to a vertebral injury.

2. 'All power of motion below my breast are gone' and no feeling below the breast suggested spinal cord damage.

3. Difficulty in breathing was mentioned only in one place despite fractures of the second and third ribs and the lung injury. Lord Nelson kept talking freely and frequently until the last minute of his life. This has ruled out the possibility of a fatal flail chest or potentially fatal tension pneumothorax.

4. He felt thirsty all the time and asked for 'fan, fan' and 'drink, drink'. He was agitated and repeatedly shouted that there was 'a gush of blood' every minute within his breast. These symptoms resembled those of vascular hypotension as a result of massive bleeding.

Of the above-mentioned conditions, the first three might not have caused death as soon as $4 \mathrm{~h}$ postinjury. Only the fourth could do so. This is supported by the report of Mr Beatty who recorded the division of a large branch of the left pulmonary artery as below. Dr Colin S White (personal correspondence, February 2004) confirmed this as the major injury leading to Nelson's early death. The following is Mr Beatty's description of the course. The authors have highlighted the entry point, the damages of anatomical structures and the final location of the ball in the report with italics.

'Course and site of the Ball, as ascertained since death' The ball struck the fore part of his Lordship's epaulette, and entered the left shoulder immediately before the processus acromion scapulae, which is slightly fractured. It then descended obliquely into the thorax, fracturing the second and third ribs; and after penetrating the left lobe of the lungs, and dividing in its passage a large branch of the left pulmonary artery, it entered the left side of the spine between the sixth and seventh dorsal vertebrae, fractured the left transverse process of the sixth dorsal vertebra, wounded the medulla spinalis, and fracturing the right transverse process of the seventh vertebra, made its way from the right side of the spine, directing its course through the muscles of the back; and lodged therein, about 2 inches below the inferior angle of the right scapula. On removing the ball, a portion of the gold-lace and pad of the epaulette, together with a small piece of his Lordship's coat, was found firmly attached to it. (W Beatty)

The trajectory could best be analysed on the horizontal anatomical section of the body (Figure 3). Assuming most trajectories take a relatively straight-line course, according to Beatty, there are two relatively straight line parts of the trajectory. The arrow in the middle part of the cadaver represents the one that involves the pulmonary artery while the one in the rear part of the cadaver that involves the spinal cord. They cannot meet and join to form a complete and continuous straight-lined trajectory. This is supported by the anatomical dissection on a cadaver by one of the authors (RP). Some mechanism must be produced to join these two sections of the trajectory to complete a continuous course of the musket ball. The following are the potential explanations.

1. There was an anatomical anomaly of posterior displacement of the left pulmonary artery far back to the rear part of the chest cavity. Such an anomaly has never been recorded.

2. $\mathrm{Mr}$ Beatty, Nelson's surgeon misinterpreted his findings at autopsy. Was it possible that a respected surgeon could have made a mistake? However, the description of 'gush' by Nelson supported bleeding from a large pulsating vessel. One of the authors (MC) suggests a different explanation that Beatty, being obliged to be distinct about the cause of

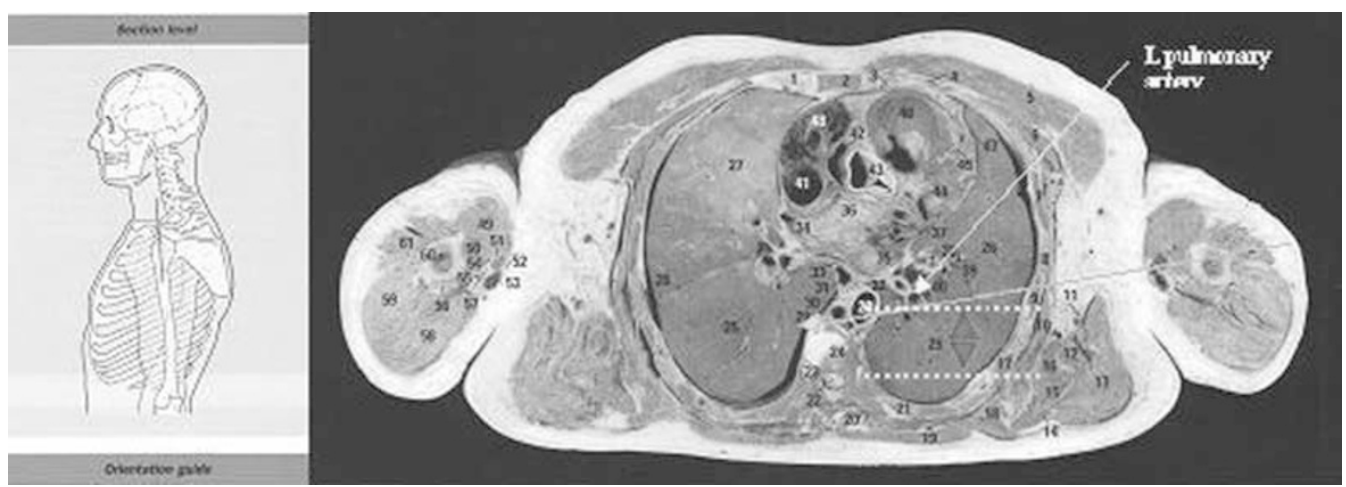

Figure 3 Anatomy of the wound. A down-up view of a horizontal section at the level of T6/7 where Nelson's spinal cord was injured. There is a big gap between the branches of the left pulmonary artery and the spinal cord. The trajectory from the acromion to the branches is equivalent to the projection of an oblique line from the acromion to the branches because on the lateral view the acromion is equivalent to the front of the shaft of humerus at the level. There must have been changes of course between the dotted lines for the musket to hit the spinal cord. (The background of anatomy is the courtesy of Ellis H, Logan BM, Dixon AK, Human Sectional Anatomy, 2nd edn., 2001, Arnold, London, New York, New Delhi, pp 115-116. The arrows, lines and the legend are the authors') 
Nelson's death had assumed a fatal injury to a major branch or the main trunk of the left pulmonary artery. This was despite, in his-own words, 'the quantity of blood thus effused did not appear to be very great', and also the Admiral had survived 3 and $1 / 4 \mathrm{~h}$. He feels that there was another explanation for the feeling of, 'a gush of blood' every minute in his breast.

3. The musket ball caused a wound tunnel of huge calibre that stretched obliquely from the chest to the back. On a horizontal cross-section view where the pulmonary artery is nearest to the back, a gap of more than $5 \mathrm{~cm}$ existson an average human body (Figure 3 ). There is no such huge cavitation in Beatty's description. Such widespread damage is possible with a modern high velocity projectile. However, a musket ball is a projectile of relatively low velocity. It could not have inflicted such extensive damage.

4. Contrary to the straight-line theory, the ball might have been knocked off its course backwards after dividing a large branch of the left pulmonary artery. All sorts of possibilities might exist. Patrick, an expert on modern firearms from the FBI Academy stated: 'Any shooting incident is a unique event, unconstrained by any natural law or physical order to follow a predetermined sequence of events or end in predetermined results. There is no valid, scientific analysis of actual shooting results in existence, or being pursued to date. It is an unfortunate vacuum because a wealth of data exists, and new data is being sadly generated every day. There are some well publicised, so called analyses of shooting incidents being promoted, however, they are greatly flawed.'

5. Similarly, Dwight, ${ }^{4}$ another expert in modern firearms pointed out that all sorts of possibilities of changing course of the projectile within the human body exist. He stressed, 'Any one who has seen many gun shot wounds must be impressed with the bizarre and unpredictable course a bullet takes when penetrating human tissues.'

6. The authors are not going to speculate further: even highly professional police forces fight shy of such speculations.
Electronic search of medical literature since 1966 and going through indices of the journal Paraplegia (now Spinal Cord) since 1963 failed to locate a single case of spinal cord injury, penetrating or nonpenetrating, that was associated with damage of a large branch of the pulmonary artery.

\section{Conclusion}

Division of a large branch of the left pulmonary artery in association with spinal cord injury was described by Lord Nelson's surgeon. It was the belief of the Maritime Establishment that his death was caused by the blood vessel injury. The damages cannot be explained by a simple relatively straight-lined trajectory. Highly professional police forces would suggest a much more complex trajectory with all sorts of nonpredetermined possibilities in ballistics analysis.

\section{Acknowledgements}

We thank Dr Colin S White, National Maritime Museum for providing us with the report of Lord Nelson's surgeon, Mr W Beatty, on His Lordship's wound that made this project possible. We are also grateful to Lady Susan Shakespeare for her advice and support of the project. Thanks also go to Andrew Wainwright, Department of Radiology, Stoke Mandeville Hospital for his painstaking attempts to create a cut through the extremely complex course of the musket ball on CT.

\section{References}

1 Death/Burial. www.aboutnelson.co.uk/death.htm (old version).

2 Death/Burial. www.aboutnelson.co.uk/death.htm (updated version).

3 Patrick UW. Handgun Wounding Factors and Effectiveness, Firearms Training Unit, FBI Academy, 14 July, 1989. http://www.pgpft.com/hgwfe.htm.

4 Dwight WR. Recovery of bullets from high-speed ammunition. Amer J Police Sci www.saf.org/LawReviews/Rife1.html. 